\title{
IAIS and Recent Developments in Insurance Regulation
}

\author{
Yoshi Kawai \\ International Association of Insurance Supervisors, c/o Bank for International Settlements, Switzerland. \\ E-mail: Yoshihiro.Kawai@bis.org
}

This paper explains the development of the International Association of Insurance Supervisors (IAIS) and its role in the establishment of essential principles for insurance supervision and regulation since its foundation 10 years ago.

The Geneva Papers (2005) 30, 29-33. doi:10.1057/palgrave.gpp.2510003

Keywords: supervision; insurance regulation; insurance core principles

\section{4 - The year when the Association took off}

The International Association of Insurance Supervisors (IAIS) was established in 1994. The first 10 years of its history (1994-2003) formed the foundation period, the time when the IAIS developed mandates, carried out fundamental activities and created the essential infrastructure. By 2003, the IAIS had developed the essential regulatory and supervisory framework, the Insurance Core Principles (ICPs) and several key principles, standards and guidance with which all insurance regulators and supervisors would strive to comply. The IAIS also created a mechanism through which insurance supervisors and regulators could learn from each other about how to improve their supervisory and regulatory systems, in particular through regional seminars in many regions around the globe. The IAIS now has an efficient Secretariat team and strong support from its members and observers.

The IAIS now expects to move even faster to cope with the rapid development of insurance markets. Insurance business in today's world is becoming ever more globalized. Many insurance companies have operations not only in their home country but around the world. In the globalized financial market, capital moves quickly and national boundaries become blurred. However, regulatory and supervisory systems are still sheltered within national boundaries. In order to address this gap, insurance regulators and supervisors should reinforce cooperation.

The year 2004 marks a new epoch for the IAIS when, supported by the strong foundation noted above, it has been able to take off and become a stronger and more transparent organization, to achieve concrete goals in each of its key activities and to cope with increasingly globalized insurance and financial markets. I will explain below where the IAIS now stands and where it will move in the years to come.

\section{Standard-setting activities}

The IAIS has developed essential principles for insurance regulation and supervision, ICPs, and key principles and standards in major areas of insurance regulation and 
supervision are now in place. The IAIS is developing more concrete and stronger principles on insurance regulations and standards.

\section{Capital adequacy and solvency}

There is no common internationally agreed standard by which capital adequacy and solvency requirements for insurers may be set or measured. The IAIS has committed itself to working to achieve convergence between the different systems for different supervisors. The Association is now drafting standards on appropriate forms of capital and on capital adequacy requirements. At the same time, the IAIS is developing a general supervisory and solvency framework, which will be a foundation for its future work on standard setting, in particular on solvency and capital requirements. The IAIS is working, not only with insurance supervisors, but also with the European Commission and the International Actuarial Association (IAA). It also communicates closely with the Basel Committee on Banking Supervision (BCBS), the IMF, the OECD and the World Bank.

\section{Accounting}

Another important IAIS activity is the setting of a common basis for regulatory reporting by insurers, so that supervisory financial reporting is consistent and system efficiency can be enhanced. The IAIS has started discussing the measurement of insurance liabilities. In parallel with this, the International Accounting Standards Board (IASB) is setting international insurance accounting standards for public financial statements, in particular on the evaluation of insurance liabilities. It is vital for insurers, reinsurers and other stakeholders that the IAIS approaches and IASB standards be consistent. To this end, the IAIS members are conferring closely with IASB members. The IAIS is represented on the IASB's Standards Advisory Council and Insurance Advisory Committee, and also has regular informal contact with IASB staff and the chair.

\section{Reinsurance}

The IAIS has set standards on the supervision of reinsurers, which state that all reinsurers should be supervised and explain how they are to be supervised. This has had a strong impact on the supervision of reinsurers in many jurisdictions that still do not sufficiently supervise reinsurers. These standards also anticipate a global approach to the regulation of reinsurers based on supervision by the home jurisdiction and by some form of accreditation of home supervisors. The IAIS is now discussing mutual recognition of reinsurance supervision so that supervisors are able to mutually recognize their reinsurance supervisory systems, while avoiding supervisory overburden. Reinsurance is a global business. The home supervisor is in charge of effective supervision of the global business of the supervised reinsurers and is to communicate effectively with supervisors in other jurisdictions where the reinsurers write business. 


\section{Transparency and disclosure}

Sound disclosure practice is the foundation for functioning markets and for maintaining confidence in insurance companies' operations. The IAIS is setting insurance companies' disclosure standards. For example, the IAIS recently drafted a disclosure standard on technical performance and risks for non-life and reinsurance companies. The IAIS is preparing to develop a disclosure standard on investment risk and the technical performance and risks for life insurance companies in the near future.

Another important area of transparency is reinsurance. In view of concerns regarding the opacity of the reinsurance industry and reinsurance companies' operations raised by the international financial community, the IAIS is developing global reinsurance market statistics and analysis in collaboration with supervisors and reinsurers from major reinsurance markets. The IAIS aims to issue the first report by the end of this year. This is a major challenge since it involves compiling data reported or disclosed under different risk management systems by reinsurers, national statutory regulations, accounting principles and confidentiality provisions.

\section{Coordination of regulatory approaches in the three financial sectors}

The IAIS, in collaboration with the BCBS and the International Organisation of Securities Commissions (IOSCO), coordinates regulatory measures and sets standards common to the three financial sectors under the aegis of the Joint Forum. At present, the IAIS contributes work to the Joint Forum on credit risk transfer, differences of financial regulation between the three financial sectors, outsourcing and liquidity risk. The IAIS is also actively taking part in the Financial Stability Forum (FSF), where high-level representatives from national authorities responsible for financial stability in significant international financial centres, international financial institutions, international groups of regulators and supervisors, and committees of central bank experts regularly exchange views.

\section{Implementation of IAIS standards}

The IAIS assists its members to implement the standards by organizing training seminars in major emerging markets and supports the Financial Sector Assessment Programme (FSAP) conducted by the IMF and the World Bank to assess the insurance regulatory and supervisory systems against IAIS standards. The IAIS recently reinforced its activities, in the following areas in particular.

\section{Core Curriculum Project}

Supervisors need concrete educational tools to learn IAIS principles and standards and to incorporate them into their insurance systems. Principles and standards are not sufficient to ensure proper implementation. Thus, the IAIS, in collaboration with the World Bank and the Financial Stability Institute, is developing educational tools to be used as learning instruments for insurance regulation and supervison in general, and 
Insurance Core Principles and IAIS standards in particular. This project, called the Core Curriculum Project, intends to develop more than 50 educational material modules in order that supervisors can study each critical regulatory and supervisory principle at both the basic and advanced levels.

\section{Law database}

The IAIS is developing an insurance law database where supervisors can learn from each other's insurance regulatory and supervisory systems. The database covers 20 key areas on insurance law and regulation from more than 50 jurisdictions.

\section{Self-assessment}

The IAIS is carrying out a self-assessment programme for its members where they can assess their observance of ICPs. This helps members to assess development of their regulatory and supervisory systems as well as their strengths and weaknesses, and to address their weaknesses. This exercise is also beneficial for preparation for the FSAP.

\section{Transparency: communication with the insurance industry}

Until recently the IAIS developed standards without organized consultation with the insurance and reinsurance industries. However, since the Association started developing concrete regulatory standards - which have had a considerable impact on insurance markets - not only insurance regulators but also insurance and reinsurance companies have paid increasing attention to its activities.

IAIS standards are therefore set in close communication with insurers and reinsurers. The standards are drafted and discussed at IAIS working parties where IAIS observers, most of whom are from insurance and reinsurance companies, often take part. The IAIS also provides various opportunities for insurance company representatives to hold discussions with representatives of insurance authorities around the world. For example, during the IAIS Annual Conference, heads of insurance authorities from 70-80 jurisdictions (not only from developed countries but also from emerging markets) meet together and have discussions with insurance company representatives.

The IAIS discloses in principle all minutes/summaries of meetings to observers within a few weeks after meetings. Thus, insurance companies can follow what the IAIS is discussing even though they do not attend the meetings.

The IAIS also discusses all its draft standards with members of working parties at an early stage. Most other international standard-setting bodies discuss their draft standards at the final stage when the standard is more or less fixed. In the case of the IAIS, it discusses the draft standards with members and observers when the paper still holds much room for improvement. The IAIS also pays heed to comments and publishes them with remarks. If comments are not accepted, the reason is clearly stated. The IAIS has spent several years establishing this transparent and open process, which contributes to the creation of useful and effective standards. 


\section{About the author}

Yoshi Kawai is Secretary General, International Association of Insurance Supervisors (IAIS); previously he was Deputy Secretary General, IAIS, and from 1995 to 1998 was Advisor to the Minister of Finance and the President of the Insurance supervisory Authority of Poland. He holds a Ph.D. from the City University, London. 